\title{
Podstawowe błędy i problemy w zastosowaniu analizy SWOT w budowie strategii rozwoju turystyki w gminie
}

\section{Basic Problems and Mistakes in the Use of SWOT Analysis in Tourism Development Strategies of Communes}

\begin{abstract}
Streszczenie: Analiza SWOT należy do najpopularniejszych i najczęściej wykorzystywanych narzędzi analizy strategicznej stosowanych w przygotowywaniu rozmaitych dokumentów, począwszy od biznesplanów, aż po różnorodne plany i strategie. Narzędzie to zyskało także znaczną popularność wśród jednostek samorządu terytorialnego przygotowujących swoje dokumenty strategiczne, w tym strategie rozwoju turystyki. $\mathrm{W}$ artykule stawiana jest hipoteza, że rozpowszechnionych zostało kilka istotnych błędów w prowadzeniu analizy SWOT. Powszechność tych błędów może wynikać ze znacznej popularności i czasem nadużywania tej metody, prowadzących do jej spłycenia. Te błędy to: zła interpretacja pojęcia „szanse”; brak refleksji nad znaczeniem wskazanych sił, słabości, szans i zagrożeń; brak obiektywizmu i nadmierny optymizm poszczególnych stwierdzeń; brak szerszego uzasadnienia dla wskazanych sił, słabości, szans i zagrożeń. Ponieważ stawiana hipoteza zakłada jedynie fakt, że wskazane błędy bywają popełniane, a nie że ich popełnianie stało się normą, dlatego wystarczającą metodą jej weryfikacji jest wskazanie ich występowania w analizowanych 10 przypadkowo wybranych strategiach rozwoju turystyki gmin w Polsce. Strategie zostały wybrane poprzez wpisanie do wyszukiwarki bing.com frazy „strategia rozwoju turystyki w gminie” i wybór pierwszych dziesięciu rekordów z wyników wyszukiwania.
\end{abstract}

\begin{abstract}
SWOT analysis is among the most popular and most commonly used methods of strategic analysis for creation of document of different types from business plans to strategic plans and strategies. This tool has also gained popularity among territorial self-governments units preparing their strategic documents, including tourism development strategies. The hypothesis that this high popularity is followed by shallowing of its idea and popularisation of few important mistakes in conduction of the analysis is made in the paper. Those mistakes are: wrong interpretation of "opportunities"; no reflection on meaning of particular strengths, weaknesses, opportunities and threats; no justification for appointing particular items; over-optimism and objective reflection missing. As the hypothesis implies only the fact that the mistakes are made from time to time and not that making them becomes a rule, it is enough to verify this hypothesis by appointing existence of stated mistakes in randomly chosen ten strategies of tourism development of ten Polish communities. The strategies were selected by typing the phrase: "strategia rozwoju turystyki w gminie" (community tourism development strategy) to bing.com search engine and selection of first ten records from the received list.
\end{abstract}


Słowa kluczowe: analiza SWOT; planowanie strategiczne; strategia rozwoju turystyki; szanse

Keywords: opportunities; strategy of tourism development; strategic planning; SWOT analysis

Otrzymano: 7 grudnia 2018

Received: 7 December 2018

Zaakceptowano: 9 lutego 2019

Accepted: 9 February 2019

\section{Sugerowana cytacja / Suggested citation:}

Żemła, M. (2019). Podstawowe błędy i problemy w zastosowaniu analizy SWOT w budowie strategii rozwoju turystyki w gminie. Prace Komisji Geografii Przemysłu Polskiego Towarzystwa Geograficznego, 33(1), 153-163. https://doi.org/10.24917/20801653.331.12

\section{WSTĘP}

Stosowanie planowania strategicznego w jednostkach samorządu terytorialnego stało się współcześnie w Polsce powszechne. W bardzo wielu gminach, powiatach i województwach elementem takiego planowania strategicznego rozwoju społeczno-gospodarczego stały się także strategie rozwoju turystyki. W strategiach tych, podobnie jak w innych dokumentach strategicznych, bardzo często, niemal zawsze, wykorzystywana jest analiza strategiczna według metody SWOT/TOWS. Niestety, popularność tej metody, a także pewne specyficzne trudności z jej prostą adaptacją powodują, że uchwalane strategie często zawierają nieścisłości lub wręcz błędy właśnie w analizach SWOT. Celem artykułu jest wskazanie kilku błędów, które są nadzwyczaj powszechne, jednak z pewnością zaproponowanej listy nie można traktować jako kompletnej. Jako weryfikację empiryczną hipotezy o popełnianiu poszczególnych błędów przez jednostki samorządu terytorialnego $\mathrm{w}$ analizach SWOT przeprowadzanych na potrzeby budowy strategii rozwoju turystyki wskazano ich występowanie w analizowanych 10 przypadkowo wybranych strategiach. Strategie te zostały wybrane poprzez wpisanie do wyszukiwarki bing.com frazy „strategia rozwoju turystyki w gminie” i wybór pierwszych 10 rekordów z wyników wyszukiwania. Taka forma weryfikacji jest wystarczająca, gdyż stawiana hipoteza zakłada jedynie, że wskazane błędy bywają popełniane, a nie że ich popełnianie stało się powszechne.

\section{ISTOTA ANALIZY SWOT}

Jednym z najczęściej wykorzystywanych narzędzi w procesie zarządzania strategicznego jest analiza SWOT. Jest ona używana zarówno do budowania strategii rozwoju o charakterze kompleksowym (ogólnych), jak i do strategii funkcjonalnych (cząstkowych) ,dotyczących którejś z funkcji przedsiębiorstwa lub państwa albo jednostki samorządu terytorialnego (Goranczewski, Puciato, 2010). Zdaniem G. Gierszewskiej i M. Romanowskiej (2002: 235) SWOT jest nie tyle jedną z metod analizy strategicznej, ile raczej „swoistym algorytmem procesu analizy strategicznej, propozycją systematycznej i wszechstronnej oceny zewnętrznych i wewnętrznych czynników określających kondycję bieżącą i potencjał rozwojowy firmy". Nazwa SWOT jest akronimem angielskich słów strengths (silne strony), weaknesses (słabe strony), opportunities (szanse), threats (zagrożenia). Główną cechą omawianej metody jest jej kompleksowy charakter wynikający z kilku faktów. Po pierwsze, dotyczy ona zarówno czynników wewnętrznych (samej organizacji), jak i zewnętrznych (otoczenia bliższego - konkurencyjnego oraz 
dalszego - makrootoczenia). Ponadto wymaga ona kompleksowej, kompletnej analizy obu tych grup czynników. Ze skrzyżowania czynników zewnętrznych i wewnętrznych powstają cztery kategorie czynników: zewnętrzne pozytywne - szanse, zewnętrzne negatywne - zagrożenia, wewnętrzne pozytywne - mocne strony, oraz wewnętrzne negatywne - słabe strony.

Za niepodważalne uznaje się w literaturze zalety metody SWOT związane z możliwością kompleksowego, spójnego ujęcia problemów funkcjonowania przedsiębiorstwa lub jednostki przestrzennej w kontekście jego warunków wewnętrznych (mocnych bądź słabych stron organizacji) oraz zewnętrznych (szans i zagrożeń stojących przed organizacją) (Napierała, 2008). W analizie SWOT z reguły nie ma jednak potrzeby wyodrębniania wszystkich czynników, należy skoncentrować się tylko na tych, które mają kluczowe znaczenie i mogą decydować o przyszłości (Goranczewski, Puciato, 2010). Istotą prawidłowo wykonanej analizy SWOT jest umiejętność wykorzystania mocnych i słabych stron oraz szans i zagrożeń, a także zapewnienie kompatybilności między zasobami analizowanego podmiotu a warunkami panującymi w jego otoczeniu. Należy zatem wykorzystywać atuty, eliminować słabości, wykorzystywać szanse oraz neutralizować zagrożenia (Gołębiowski, 2001).

Jednak znaczna prostota metody powoduje także, że bywa ona w literaturze przedmiotu krytykowana i wskazywane są jej słabe strony, a także propozycje usprawnień. Szerokiego przeglądu takich argumentów oraz propozycji dokonuje m.in. T. Napierała (2008). Wskazuje on przede wszystkim na istotne uproszczenia wykorzystywanego warsztatu, co prowadzić może do otrzymywania mało obiektywnych rezultatów. Metoda ta jest także bardzo podatna na błędy, których popełnianie prowadzi do otrzymania niewiarygodnych wyników. W pierwszej kolejności Napierała wskazuje tu na swego rodzaju mit, iż metoda SWOT sama w sobie dysponuje możliwościami analitycznymi, choć w rzeczywistości jest ona wyłącznie szkieletem dla wielorakich, analitycznych metod zewnętrznego i wewnętrznego audytu. Zatem poprawne przeprowadzenie analizy SWOT wymaga wcześniejszego, odpowiedniego przeprowadzenia analizy zasobów i otoczenia, a SWOT pomaga jedynie w efektywnym zestawieniu wyników tych analiz i powinna prowadzić do otrzymania wartościowych wniosków. Zapominanie o tej zasadzie, zdaniem T. Napierały (2008), prowadzić może do sytuacji, w której jakiekolwiek czynniki zdefiniowane dzięki metodzie SWOT mogą być błędnie uznane za wiarygodną podstawę podejmowania decyzji strategicznych. Cytując argumenty T.J. Chermack i B.K. Kasshanny (2007), autor ten wskazuje także kolejne swego rodzaju mity, które narosły wokół analizy SWOT:

- metoda SWOT winna być realizowana wyłącznie na poziomie całego przedsiębiorstwa;

- metoda SWOT realizowana jest wyłącznie na podstawie analizy bieżącej pozycji konkurencyjnej przedsiębiorstwa,

- zawartość listy mocnych i słabych stron organizacji oraz szans i zagrożeń rozwoju przedsiębiorstwa nie jest zależna od strategii, jaką przedsiębiorstwo zamierza wdrożyć;

- analiza porównawcza może zostać zrealizowana wyłącznie dla wybranych, aktualnych i najbliższych podmiotów konkurujących z przedsiębiorstwem,

- analiza porównawcza może zostać zrealizowana wyłącznie dla rynku lokalnego.

Warto zauważyć, że powyższe zarzuty w zasadzie nie odnoszą się do istoty samej analizy SWOT, co raczej prezentują pewne błędne postawy w procesie planowania strategicznego, które mogą się ujawnić także przy stosowaniu innych metod analizy 
strategicznej, jednak wydaje się, że sama analiza SWOT może stanowić swego rodzaju zachętę do takich uproszczeń w procesie analitycznym.

Natomiast M. Asejczyk-Woroniecka (2016) wskazuje na następujące problemy związane z wykorzystaniem analizy SWOT w planowaniu strategicznym:

- jej wyniki są subiektywne, zbyt banalne i oczywiste;

- brak dowodów jej skuteczności;

- podział czynników na dwie kategorie, czyli na pozytywne i negatywne, jest zbytnim uproszczeniem;

- zdarzają się czynniki, które nie pasują do żadnej z czterech kategorii;

- brak analizy przyczyn słabych stron;

- zlecanie przeprowadzenia analizy SWOT firmie zewnętrznej może powodować brak dopasowania wyników analizy do danej organizacji.

Szczególnie ważnym etapem prawidłowo przeprowadzonej analizy SWOT jest proces wnioskowania na podstawie zidentyfikowanych sił, słabości, szans i zagrożeń. W literaturze można znaleźć kilka mniej lub bardziej szczegółowych sugestii, w jaki sposób ten proces powinien przebiegać. Jedną z częściej przywoływanych propozycji jest podział całego procesu prowadzenia analizy na cztery etapy (Obłój, 2001; Bieda, Brzozowska, 2017):

1. Określenie oraz opisanie czynników wewnętrznych i zewnętrznych, które mogą mieć pozytywny i negatywny wpływ na rozwój organizacji.

2. Przypisanie poszczególnym czynnikom znaczenia poprzez określenie wag.

3. Analiza wzajemnych powiązania wybranych czynników poprzez odpowiedź na pytania oraz oznaczenie relacji jako istniejące lub nieistniejące

a) w analizie SWOT:

- czy mocna strona pozwoli wykorzystać daną szansę?

- czy mocna strona pozwoli zniwelować dane zagrożenie?

- czy słaba strona ogranicza możliwość wykorzystania danej szansy?

- czy słaba strona potęguje ryzyko związane z danym zagrożeniem?

b) w analizie TOWS:

- czy szansa wzmacnia daną silną stronę?

- czy szansa pozwala zniwelować daną słabość?

- czy zagrożenie niweluje daną silną stronę?

- czy zagrożenie uwypukla daną słabość?

4. Wybór odpowiedniej strategii.

Powyższe zestawienie wskazuje, że możliwe są dwa podejścia do zestawiania ze sobą sił, słabości, szans i zagrożeń, które noszą odpowiednio nazwy SWOT i TOWS, dlatego cała procedura analityczna w licznych publikacjach określana jest jako analiza SWOT/TOWS (Żabińska, 1997; Żabiński, 2000; Niestrój, 2002; Bieda, Brzozowska, 2017; Kucharczyk, Kardas, 2018). W podejściu SWOT ocenie podlega wpływ elementów analizy zasobów na elementy otoczenia, w podejściu TOWS kierunek wnioskowania jest odwrotny.

W literaturze prezentowanych jest również kilka podejść do budowy strategii rozwoju w oparciu o wyniki analizy SWOT/TOWS. Zdecydowanie najczęściej proponowane podejście zakłada zestawienie ze sobą sił ze słabościami i szans z zagrożeniami, w celu odpowiedzi, czy badany podmiot ma przewagę sił nad słabościami (lub odwrotnie) oraz czy sytuacja w otoczeniu jest sprzyjająca (przewaga szans) lub niesprzyjająca (przewaga zagrożeń) (Gierszewska, Romanowska, 2002). W wyniku nałożenia na 
siebie wyników takiego wnioskowania każdy analizowany podmiot powinien realizować jedną z czterech możliwych ogólnych strategii rozwoju:

- gdy otoczenie sprzyja, a podmiot jest silny: strategia agresywna (maksi-maksi) jej zadaniem jest wykorzystanie mocnych stron przedsiębiorstwa oraz umocnienie szans zewnętrznych (Cholewicka-Goździk, 2009); polega na maksymalnym wykorzystaniu tych czynników, które spowodują silną ekspansję i rozwój firmy; strategia agresywna (maksi-maksi) polega na maksymalnym wykorzystaniu efektu synergii występującego między silnymi stronami organizacji a szansami generowanymi przez otoczenie (Obłój, 2001);

- gdy otoczenie jest niesprzyjające, a podmiot silny: strategia konserwatywna (maksi-mini) - należy zminimalizować negatywne wpływy otoczenia, a także wykorzystać mocne strony przedsiębiorstwa (Gierszewska, Romanowska, 2002; Cholewicka-Goździk, 2009); w ramach strategii należy dokonać segmentacji rynku lub selekcji produktów, bądź też poszukać nowych rynków zbytu dla naszych produktów (Klasik, 1993);

- gdy otoczenie nie sprzyja, a podmiot jest słaby: strategia defensywna (mini-mini) - jej celem jest minimalizacja słabości i unikanie zagrożeń (Kucharczyk, Kardas, 2018); w wersji pesymistycznej podmiot powinien zmienić dominujące funkcje, a w przypadku podmiotów komercyjnych jest nawet rozważana likwidacja firmy lub połączenie z silniejszym konkurentem, zaś w wariancie optymistycznym podmiot powinien próbować przetrwać trudny okres, pozyskując nowe źródła finansowania i oczekując na zmiany w otoczeniu sprzyjające rozwojowi (Gierszewska, Romanowska, 2002);

- gdy otoczenie nie sprzyja, a podmiot jest mocny: strategia konkurencyjna (minimaksi) - polegająca na eliminowaniu słabych stron funkcjonowania organizacji oraz budowaniu jej konkurencyjnej siły przez maksymalne wykorzystanie istniejących szans sprzyjających rozwojowi (Obłój, 2001); obejmuje działania, które zwiększą zasoby finansowe oraz handlowe, polepszą linię produkcyjną, poprawią produktywność, zredukują koszty, spowodują utrzymanie mocnej pozycji konkurencyjnej (Klasik, 1993).

Wśród problemów z zastosowaniem powyższego podejścia do budowy strategii można wymienić brak jednoznacznych wskazówek co do sposobu oceny przewagi sił lub słabości oraz szans lub zagrożeń, który może prowadzić do stwierdzeń subiektywnych i zbyt radykalnych wniosków. Bardziej złożoną metodę budowy strategii w oparciu o wyniki analizy SWOT proponuje R. Niestrój (2002). Istotą tego podejścia jest odejście od problematycznego określania przewagi szans nad zagrożeniami i sił nad słabościami (bądź odwrotnie) na rzecz określenia siły tych elementów. Najpierw zatem oceniane jest otoczenie, w którym możliwe są cztery sytuacje:

- idealne okazje - czyli sytuacja, w której szanse są duże, a zagrożenia niewielkie;

- interesy ustabilizowane - szanse i zagrożenia są małe;

- interesy spekulacyjne - szanse i zagrożenia są duże;

- przedsięwzięcia kłopotliwe - szanse są małe, a zagrożenia znaczne.

Podobnie wyodrębniane są cztery możliwe sytuacje, jeśli chodzi o stan zasobów:

- bezwzględna przewaga - czyli sytuacja, w której siły są duże, a słabości nieznaczne;

- przeciętna - siły i słabości są małe;

- przewaga oparta na wybranych atutach - siły i słabości są duże;

- przewaga słabości - siły są niewielkie, a słabości duże. 
W wyniku zestawienia ze sobą czterech możliwych stanów zasobów i czterech możliwych stanów otoczenia powstaje szesnastopolowa macierz zawierająca wskazania strategiczne, odrębne dla każdego z pól (Niestrój, 2002: 126).

Warto zauważyć, że metoda SWOT powstała na potrzeby planowania strategicznego $\mathrm{w}$ przedsiębiorstwach, obecnie stosowana jest powszechnie także przez organizacje non profit czy jednostki samorządu terytorialnego, również na potrzeby planowania rozwoju funkcji turystycznej na ich obszarze. Pomimo że, co zostało wcześniej podkreślone, metoda SWOT należy do metod stosunkowo prostych w zastosowaniu, jej adaptacja na potrzeby planowania rozwoju turystyki w obszarze jednostek samorządu terytorialnego może powodować dodatkowe trudności oraz prowadzić do nieporozumień i błędów, zarówno takich, które bywają popełniane w analizie na potrzeby przedsiębiorstw, jak i takich, które są bardzo typowe dla jednostek samorządu terytorialnego.

\section{BŁĘDY I PROBLEMY DOSTRZEŻONE W WYBRANYCH STRATEGIACH}

Aby zweryfikować hipotezę o występowaniu błędów w uchwalanych strategiach rozwoju turystyki w gminach w Polsce, 18 października 2018 roku do wyszukiwarki bing.com wpisano frazę „strategia rozwoju turystyki w gminie” i wybrano pierwsze dziesięć rekordów, które prowadziły do konkretnych dokumentów strategicznych. W ten sposób wybrano następujące strategie:

1. Strategia rozwoju turystyki w gminie Głuchołazy.

2. Strategia rozwoju turystyki miasta i gminy Busko-Zdrój na lata 2011-2020.

3. Strategia rozwoju turystyki w gminach: Wałbrzych, Świebodzice, Boguszów-Gorce, Szczawno-Zdrój, Jedlina-Zdrój, Mieroszów, Walim, Głuszyca oraz w powiecie wałbrzyskim na tle subregionu turystycznego Góry Wałbrzyskie.

4. Strategia rozwoju w zakresie kultury, rekreacji, sportu i turystyki na terenie gminy Mogilany.

5. Strategia rozwoju turystyki i współpracy transgranicznej gmin Leśniowice, Żmudź, Wojsławice, Dorohusk i gminy Huszcza.

6. Strategia rozwoju turystyki w gminie Andrychów.

7. Strategia rozwoju gminy Koronowo na lata 2016-2025.

8. Strategia rozwoju turystyki na obszarze transgranicznym na lata 2014-2018 (dla gminy Rajcza wraz z sąsiednimi gminami w Polsce i na Słowacji).

9. Kraina Jeziora Mucharskiego. Strategia rozwoju turystyki.

10. Strategia rozwoju turystyki w gminie Borne Sulinowo na lata 2009-2015.

We wszystkich wytypowanych dokumentach strategicznych znalazła się analiza strategiczna metodą SWOT. Na podstawie lektury analiz SWOT zamieszczonych w wybranych dokumentach strategicznych można wskazać występowanie w nich kilku typowych problemów i błędów:

- brak refleksji strategicznej nad wyodrębnionymi siłami, szansami, słabościami i zagrożeniami,

- brak informacji o metodzie prowadzącej do wskazania konkretnych sił, słabości, szans i zagrożeń, brak pewności co do kompletności listy,

- brak obiektywizmu i zbyt optymistyczne określanie sił, słabości, szans i zagrożeń oraz ich znaczenia i/lub nadmierna szczegółowość niektórych sformułowań,

- błędne definiowanie szans. 
Ponieważ celem artykułu nie jest ocena merytoryczna ani metodologiczna poszczególnych omawianych strategii, ani tym bardziej próba wskazania tych spośród nich, które zawierają więcej czy mniej niedociągnięć metodologicznych, w dalszej części artykułu nie będą podawane tytuły poszczególnych dokumentów, w których zidentyfikowano poszczególne błędy, a w przykładowych cytowanych zapisach, w miarę możliwości, pomijane będą elementy pozwalające na łatwą identyfikację poszczególnych gmin.

\section{Brak refleksji strategicznej nad wyodrębnionymi siłami, szansami, słabościami i zagrożeniami}

Zgodnie z przytaczanymi wcześniej cenionymi pozycjami bibliograficznymi efektem prowadzenia analizy SWOT nie powinno być jedynie wskazanie sił, słabości, szans i zagrożeń, ale analiza ta powinna prowadzić do wskazania wniosków i określenia pożądanych kierunków działań, najlepiej wyrażonych w formie konkretnej ogólnej strategii rozwoju. Zasadzie tej niemal całkowicie przeczy zawartość analizowanych strategii. Aż w sześciu przypadkach analiza SWOT kończy się na wymienieniu czterech powyższych elementów, po których nie następują żadne wnioski. Co więcej, w pozostałych przypadkach mamy do czynienia jedynie z bardzo ogólnym omówieniem wyników analizy i ewentualnym zarysowaniem wniosków, które w jednej ze strategii w zasadzie w ogóle nie są powiązane z treścią analizy. Jedynie w jednej strategii analiza danych zawartych w SWOT obejmuje omówienie synergii między poszczególnymi elementami, jednak nawet $\mathrm{w}$ tym dokumencie brakuje wyboru strategii rozwoju.

\section{Brak informacji o metodzie prowadzącej do wskazania konkretnych sił, słabości, szans i zagrożeń}

Jedną z najważniejszych słabości metody SWOT, wskazywanej we wcześniejszej części artykułu, jest jej wrażliwość na znaczny subiektywizm i niekompletność wyników. Co więcej, wielu cytowanych autorów podkreśla, że metody SWOT w ogóle nie powinno się traktować jako metody prowadzenia analizy, ale jedynie jako sposób porządkowania wyników wcześniej prowadzonych analiz. Warto zatem przyjrzeć się informacjom zawartym w analizowanych strategiach dotyczących metody i zakresu gromadzenia danych, które następnie były prezentowane jako siły, słabości, szanse i zagrożenia. W dwóch analizowanych strategiach nie ma żadnych informacji o sposobie wskazywania tych czterech elementów, w pozostałych pojawiają się informacje na temat warsztatów z lokalnymi interesariuszami, podczas których te elementy były dyskutowane i/lub prezentacja wyników analizy sytuacji. Z reguły jednak informacja o prowadzonych warsztatach jest mało precyzyjna i nie wynika z niej metoda pracy z uczestnikami ani zakres tematyczny. Jeszcze więcej zastrzeżeń budzi prezentacja analizy sytuacji, tam gdzie jest ona zawarta, czyli w sześciu dokumentach. W każdym z nich diagnoza stanu ograniczona jest wyłącznie do analizy wewnętrznej, nie ma żadnych informacji o zjawiskach zachodzących w otoczeniu. W takiej sytuacji, w oczywisty sposób, prezentowane siły, słabości, a zwłaszcza szanse i zagrożenia, muszą budzić obawy, że są to elementy przypadkowe, wybrane i ocenione subiektywnie, a z pewnością, że prezentowane listy mogą być mocno niekompletne. Wiele z tych wątpliwości znajduje zresztą pełne potwierdzenie w szczegółowej analizie zapisów poszczególnych strategii prezentowanej poniżej. 


\section{Brak obiektywizmu i zbyt optymistyczne określanie sił, słabości, szans i zagrożeń}

O ile zweryfikowanie poprawności lub braku poprawności analizowanych strategii w świetle dwóch powyższych punktów jest procesem jednoznacznym, o tyle stawianie zarzutów o brak obiektywizmu zawsze może się stać przedmiotem podobnej krytyki i także obarczone jest pewną dozą subiektywizmu, dodatkowo wzmacnianą bardzo zróżnicowaną wiedzą badacza na temat lokalnych uwarunkowań w poszczególnych obszarach. Dlatego w niniejszym punkcie zwrócono uwagę na sytuacje, w których nazbyt optymistyczne podejście do formułowania sił, słabości, szans i zagrożeń, a także wniosków nie budzi wątpliwości. Ten brak obiektywizmu przejawia się najczęściej w jednej z dwóch form: bądź w samej strukturze analizy, bądź w treści poszczególnych zapisów. Pierwszą sytuację można zaobserwować w sposób bardzo klarowny w jednej ze strategii, w której wskazana została ogromna liczba sił, bardzo rozdrobnionych i szczegółowych oraz uporządkowanych według kategorii, a po nich następuje prezentacja jedynie kilku słabości, podanych w sposób bardzo ogólny i bez dzielenia na kategorie. Wydaje się jednak, że tendencja do mnożenia sił i szans oraz wydłużania ich listy nieco na siłę może być zaobserwowana niemal we wszystkich analizowanych dokumentach, jednak w większości przypadków działanie to zostało przeprowadzone w zdecydowanie bardziej dyskretny sposób. Dość ewidentnie szanse mnożone są w innym dokumencie, w którym jednocześnie wskazane zostały: „możliwość promowania gminy jako miejsca czystego ekologicznie” oraz „wykorzystanie mało przekształconego środowiska do rozwoju bardziej dochodowych form produkcji rolnej oraz rozwoju turystyki”, a także „wykorzystanie internetu jako źródła promocji, sprzedaży i dystrybucji oferty” oraz „rozwój technologii IT w turystyce”.

Dużo łatwiej wskazać konkretne przykłady zapisów, które zawierają sporą dawkę optymizmu. W poszczególnych strategiach chętnie przywoływane są jako szanse różne tendencje na krajowym i międzynarodowym rynku turystycznym. Przykładowo w jednej ze strategii na potrzeby gminy wiejskiej o zdecydowanie peryferyjnym położeniu, słabej dostępności komunikacyjnej i bazie noclegowej jako szansa wskazana została „Szybko rozwijająca się turystyka biznesowa”. W kilku strategiach jako szansa przywoływany jest „rozwój nowoczesnych technologii, zwłaszcza informatycznych i telekomunikacyjnych oraz możliwość ich wykorzystania w celu poprawy konkurencyjności oferty". Biorąc pod uwagę, że analizowane strategie w większości dotyczą obszarów peryferyjnych, o ograniczonych zasobach, także finansowych i ludzkich, warto się zastanowić, czy nowe technologie stanowią dla tego typu obszarów recepcji turystycznej jedynie szanse, czy także zagrożenie związane z powiększeniem się dystansu do rynkowych liderów. Dużo bardziej „kreatywnie” do pozytywnej oceny sytuacji autorzy poszczególnych strategii podeszli w analizie zasobów. W przypadku gminy o znaczących walorach turystycznych i bardzo słabym jej zagospodarowaniu jako siła wskazana jest „dobra baza noclegowa”. W przypadku innej gminy jako atut wskazany został fakt, że jest ona „znanym w Polsce ośrodkiem krajoznawczym, ze znaną marką turystyczną" - łatwo zauważyć, że w zasadzie takiej marki nie ma żadna z gmin, których strategie poddano analizie. W innym zapisie jako siła wskazana została „bliskość autostrady”. Jest to zapis budzący pewne wątpliwości w sytuacji, gdy gmina położona jest ponad 50 km od wspomnianej autostrady, a dojazd zajmuje blisko godzinę (dane na podstawie google.maps.pl). 
Oprócz zapisów, które budzą kontrowersje i zawierają raczej „chciejstwo” autorów niż obiektywny opis stanu, listy szans i sił są wydłużane przez zapisy prawdziwe, lecz trywialne i/lub niezwiązane z tematem. Przykładami tych pierwszych są sformułowania typu „dogodne warunki do rozwoju turystyki i rekreacji”, „,walory krajobrazowo-przyrodnicze”, „rozwój turystyki kwalifikowanej w Polsce” czy „ponadprzeciętne walory historyczne, kulturalne i przyrodnicze”. W innych dokumentach można przeczytać, że siłą lub szansą są „liczne i aktywne ochotnicze straże pożarne”, „znaczne zasoby siły roboczej”, „dobrze przygotowana kadra w pozyskiwaniu środków UE”,czy, potencjał ludzki". Bardzo ciekawy jest też zapis jednej ze strategii, mówiący, iż szansą dla gminy jest „powstanie drogi łączącej gminy X i Y”. Problem w tym, że jest to szansa dość hipotetyczna, gdyż taka droga nie była i nadal nie jest planowana. Innym interesującym przypadkiem jest zamieszczenie w tej samej analizie siły „rozbudowana baza noclegowa” i słabości „zbyt skromna i mało zróżnicowana baza noclegowa”.

Brak obiektywizmu widoczny jest także w sposobie wyciągania wniosków w tych dokumentach, w których takowe w ogóle są wyciągane. Oprócz braku obiektywizmu ważnym problemem wnioskowania, widocznym w części analizowanych strategii, jest oderwanie wniosków od wcześniej wskazanych sił, słabości, szans i zagrożeń. Pomimo że w żadnej ze strategii nie wysuwa się propozycji formalnej strategii rozwoju, to jednak końcowe wnioski są (jeśli są) dość optymistyczne, np. „Silne strony przeważają nad słabymi, ale ilość szans i zagrożeń jest zrównoważona". Jeszcze w innym dokumencie znalazł się mało klarowny wniosek mówiący, że „przychylne dla różnych gałęzi rolnictwa możliwości i warunki naturalne sprawiają, że może rozwijać się szeroko rozumiana turystyka kwalifikowana".

\section{Błędne definiowanie szans}

Błędy i niedociągnięcia w poprzednich punktach teoretycznie miały większą wagę, gdyż dotyczyły kwestii metodologii prowadzenia analizy, natomiast te prezentowane w poniższym punkcie związane są jedynie z poszczególnymi zapisami. Jednak część ze wskazanych powyżej zastrzeżeń mogłaby zostać osłabiona, gdyż - być może - wynikają one z błędów nie tyle w prowadzeniu analizy, ile w sposobie jej zapisu (np. brak informacji o metodzie gromadzenia informacji, brak wniosków itp.). Niewykluczone, że autorzy poszczególnych dokumentów wykonali potrzebne działania, a jedynie nie zamieścili precyzyjnej informacji o nich w oficjalnym dokumencie. Inaczej jest z bardzo typowym błędem dotyczącym określania szans. Jest to jedynie błąd dotyczący poszczególnych zapisów, ale jego wystąpienie sugeruje jednoznacznie popełnienie istotnej pomyłki metodologicznej na etapie analizy. Błąd ten polega na przyjęciu potocznego znaczenia słowa „szansa” i wskazywania zadań, których wykonanie będzie stanowiło dla danej gminy szansę. W ten sposób w analizowanych strategiach jako szanse zostały wskazane m.in.: „podjęcie skutecznych działań zmierzających do powstawania nowych produktów turystycznych oraz podjęcie nowoczesnych metod ich sprzedawania”; „utworzenie klastra turystycznego”, ,,budowa odpowiedniej infrastruktury turystycznej”, ,promocja produktów regionalnych”, „opracowanie miejscowych planów zagospodarowania przestrzennego”, , podniesienie atrakcyjności gminy poprzez kampanię wizerunkową”, ,,rozwój lokalnego produktu turystycznego" czy wiele innych. Trzeba w tym miejscu podkreślić, że tego typu zapisy w analizowanych strategiach nie występują sporadycznie, ale są powszechne. Jedynie w dwóch spośród badanych dokumentów nie stwierdzono 
występowania tego typu błędu, natomiast w kolejnych dwóch błędnie określona została zdecydowana większość lub nawet wszystkie zidentyfikowane szanse.

Potoczne pojmowanie szans w analizie SWOT nie jest typowe tylko dla planowania rozwoju jednostek samorządu terytorialnego, warto jednak podkreślić, że w tym przypadku określenie i oddzielenie od siebie czynników wewnętrznych i zewnętrznych analizy sytuacji jest trudniejsze niż w przypadku przedsiębiorstw. Można mieć wątpliwości, czy np. potencjał ludzki analizowanej gminy należy uznać w przypadku planowania rozwoju funkcji turystycznej za czynnik wewnętrzny, co byłoby bardziej oczywiste, czy za zewnętrzny, gdyż niezwiązany bezpośrednio z tą funkcją. Takich wątpliwości jest więcej i znajdują one odzwierciedlenie także w zapisach badanych strategii. Przykładowo „obawa mieszkańców gminy przed podejmowaniem działań agroturystycznych” powinna być raczej rozpatrywana jako słabość, jednak w jednej z badanych strategii została zakwalifikowana jako zagrożenie.

O ile błędne, potoczne rozumienie słowa „szanse” w analizie SWOT jest, jak pokazuje przykład analizowanych dokumentów, powszechne, o tyle można też wskazać pojedyncze przykłady błędnej klasyfikacji innych zidentyfikowanych czynników. Przykładowo w jednym z dokumentów „konkurencja innych gmin” została określona jako słabość, a w innym „wizerunek przemysłowy gminy” jako zagrożenie.

\section{PODSUMOWANIE}

Analiza przypadkowo wybranych strategii rozwoju turystyki w gminie wykazała, że metoda SWOT, powszechnie stosowana w części analitycznej dokumentów, pomimo swojej relatywnej prostoty często wykonywana jest w sposób mało precyzyjny lub wręcz błędny. Potwierdzenie znalazła także hipoteza wskazująca na występowanie typowych błędów metodologicznych. W każdym z badanych dokumentów zidentyfikowano występowanie co najmniej jednego ze wskazanych problemów, w większości dokumentów pojawiły się one wszystkie. Można zatem wskazać, że uświadomienie decydentów oraz wykonawców strategii w kwestii wymienionych problemów, jak również prawidłowe kształcenie przyszłych kadr na poziomie uniwersyteckim powinno zwrócić szczególną uwagę na badane w tym artykule zagadnienia, a więc: brak refleksji strategicznej nad wyodrębnionymi siłami, szansami, słabościami i zagrożeniami; brak informacji o metodzie prowadzącej do wskazania konkretnych sił, słabości, szans i zagrożeń, brak pewności co do kompletności listy; brak obiektywizmu i zbyt optymistyczne określanie sił, słabości, szans i zagrożeń oraz ich znaczenia i/lub nadmierna szczegółowość niektórych sformułowań oraz błędne definiowanie szans. Stwierdzenie to wydaje się tym ważniejsze, że analizowane dokumenty strategiczne zdają się nie tylko potwierdzać fakt sporadycznego występowania tych błędów, ale sugerują wręcz ich powszechność, co każe stawiać pod znakiem zapytania wartość merytoryczną celów i planów opartych na niepełnych i/lub błędnych analizach.

\section{Literatura \\ References}

Asejczyk-Woroniecka, M. (2016). Zastosowanie analizy SWOT w doskonaleniu zarządzania jednostkami administracji terytorialnej. Finanse, Rynki Finansowe, Ubezpieczenia, 6(84), 311321. 
Bieda, A., Brzozowska, A. (2017). Analiza SWOT/TOWS jako metoda określania kierunków rozwoju przestrzennego. Acta Sci. Pol. Administratio Locorum, 16(3), 151-160.

Chermack, T.J., Kasshanna, B.K. (2007). The use and misuse of SWOT analysis and implication for HRD professionals. Human Recourses Development International, 10(4), 383-399.

Cholewicka-Goździk K., (2009). Analiza SWOT - instrument wyboru strategii i polityki jakości. Problemy Jakości, 2, 10-11.

Gierszewska, G., Romanowska, M. (2002). Analiza strategiczna przedsiębiorstwa. Warszawa: Państwowe Wydawnictwo Ekonomiczne.

Gołębiowski, T. (2001). Zarzq̨dzanie strategiczne. Planowanie i kontrola. Warszawa: Difin.

Goranczewski, B., Puciato, D. (2010). Zastosowanie analizy SWOT w formułowaniu strategii rozwoju turystyki na obszarach recepcyjnych. Turyzm, 20(2), 47-55.

Klasik, A., (1993). Planowanie strategiczne. Warszawa: Państwowe Wydawnictwo Ekonomiczne.

Kucharczyk, A., Kardas, E. (2018). Ocena potencjału wybranego przedsięwzięcia za pomocą analizy SWOT/TOWS. Archiwum Wiedzy Inżynierskiej, 3(1), 3-7.

Napierała, T. (2008). Analiza SWOT w małym przedsiębiorstwie turystycznym. Turystyka i Hotelarstwo, 14, 33-51.

Niestrój, R. (2002). Zarządzanie marketingiem. Aspekty strategiczne. Warszawa: Wydawnictwo Naukowe PWN.

Obłój, K. (2001). Strategia organizacji. Warszawa: Polskie Wydawnictwo Ekonomiczne.

Żabińska, T. (1997). Analiza strategiczna gminy na potrzeby wyboru strategii rozwoju za pomocą analizy SWOT. Katowice: Wydawnictwo Akademii Ekonomicznej w Katowicach.

Żabiński, L. (2000). Analiza strategiczna przedsiębiorstwa na potrzeby wyboru strategii rozwoju (za pomocą metody SWOT). Katowice: Wydawnictwo Akademii Ekonomicznej w Katowicach.

Michał Żemła, dr hab., prof. nadzw. w Zakładzie Turystyki i Badań Regionalnych Instytutu Geografii Uniwersytetu Pedagogicznego w Krakowie. Autor licznych publikacji związanych z marketingiem i konkurencyjnością produktu obszaru turystycznego. Przedmiotem jego szczególnego zainteresowania jest rozwój turystyki na obszarach górskich, a zwłaszcza ośrodków turystyki narciarskiej i turystyki pieszej.

Michał Żemła, PhD, associate professor in the Department of Tourism and Regional Studies, Institute of Geography, Pedagogical University of Cracow. The author of numerous publications on destination's product marketing and competitiveness. His main interest is the development of tourism in mountain areas with special regard to winter sports and hiking tourism.

ORCID: 0000-0002-3521-8128

\section{Adres/address:}

Uniwersytet Pedagogiczny w Krakowie

Wydział Geograficzno-Biologiczny

Instytut Geografii

ul. Podchorążych 2, 30-084 Kraków, Polska

e-mail:michal.zemla@up.krakow.pl 